\title{
A spatiotemporal analysis of dengue hemorrhagic fever in Banyumas, Indonesia
}

\author{
Dwi Sarwani Sri Rejeki ${ }^{1}$, Nunung Nurhayati ${ }^{2}$, Budi Aji ${ }^{3}$ \\ ${ }^{1,3}$ Department of Public Health, Faculty of Health Sciences, Universitas Jenderal Soedirman, Indonesia \\ ${ }^{2}$ Department of Mathematics, Faculty of Mathematics and Science, Universitas Jenderal Soedirman, Indonesia
}

\begin{abstract}
Article Info
Article history:

Received Oct 23, 2020

Revised Feb 19, 2021

Accepted Mar 5, 2021

\section{Keywords:}

Dengue hemorrhagic fever Geographic determination Risk zones

Spatiotemporal

Transmission

Variation

ABSTRACT

Dengue hemorrhagic fever (DHF) is a public health problem in the world and also in Indonesia. One of the districts in Central Java that is still having problems with this disease is Banyumas, Indonesia. The incidence rate (IR) data in 2018 was 2.75 per 100,000 populations and the case fatality rate (CFR) was $3.64 \%$. Spatiotemporal analysis was used to determine local variation, geographic determination of risk zones, and measurement of disease control interventions. Therefore, this study aimed to determine the distribution and grouping of dengue cases based on the spatiotemporal analysis. The design was observational with a cross-sectional spatial analysis. This study was conducted in Banyumas, Indonesia with the analysis unit for dengue fever patients in 2018 using as many as 57 cases. Furthermore, the data analysis used includes overlay, buffering, and clustering with SaTScan and ArcGis software. The results showed that there was a clustering of dengue cases in Banyumas, with one primary and three secondary clusters detected. The primary cluster occurred in March-April 2018, involving four sub-districts in urban areas. It was then concluded that the significantly identified clusters indicate a transmission of dengue fever in the Banyumas area with a radius of three kilometers.
\end{abstract}

This is an open access article under the CC BY-SA license.

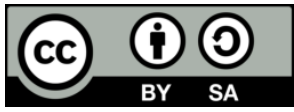

\section{Corresponding Author:}

Dwi Sarwani Sri Rejeki

Department of Public Health, Faculty of Health Sciences

Universitas Jenderal Soedirman

Suparno Street, Karangwangkal, Purwokerto, Central Java, Indonesia

Email: dwisarwanisr@yahoo.com

\section{INTRODUCTION}

Dengue hemorrhagic fever (DHF) is a vector-borne disease that is widespread in the world, especially in tropical and subtropical climates. This infection is caused by the dengue virus which is transmitted from Aedes aegpty or Aedes albopictus mosquito species. According to WHO, Asia Pacific bore $75 \%$ of the world's dengue burden between 2004 and 2010, while Indonesia was reported as the 2nd country with the largest cases among 30 endemic countries [1]. The Indonesian Ministry of Health recorded dengue fever incidence rate (IR) of 50.75 per 100,000 populations in 2015 , with a case fatality rate (CFR) of $0.82 \%$. This figure increased in 2016 with an IR of 79.92 per 100,000 populations and a CFR of $0.78 \%$. However, the number of cases decreased in 2017 , with IR recorded at 26.12 per 100,000 population and a CFR of $0.72 \%[2]$.

Banyumas is a contributor to dengue cases in Central Java. The number of cases in Banyumas was 264 in 2015 (IR=16.43), 990 in 2016 (IR=55.07), and 68 in 2017 (IR=3.35). In 2018, DHF cases decreased to 55 (IR 2.75 per 100,000) and the CFR value was 3.64\% [3]. The results of a qualitative study of DHF control 
program in Banyumas showed that the input components of the prevention and control program (funds, methods, and time) are relatively sufficient. However, the implementation of programs such as fogging focus, larvicide, regular eradication of mosquito nests is still not optimal [4].

Geospatial analysis is useful in controlling vector-borne diseases such as dengue and malaria. This analysis is a spatial aspect that shows the location and position of an object or event that is below, on, or above the earth's surface which is stated in a certain coordinate system [5]. Changing spatial data into geospatial information requires a geographical information system (GIS) and spatial analysis. Furthermore, the Geographic information systems are to determine the analysis of local variations and geographic risk zones, as well as to measure disease control interventions [6]. The combination of spatial and time aspects is called spatiotemporal. The results of the systematic review of dengue fever showed a useful spatial analysis in the public health sector, including identifying the risk of the fever. This method is used to advance scientific knowledge about the dynamics of dengue transmission, surveillance strategies, and to reduce the social costs associated with the transmission [7].

The spatial analysis of DHF in Putrajaya, Malaysia showed that the incidence of dengue occurs in clusters with an average radius of 264 meters [8]. Furthermore, findings in Taiwan showed that there is a spatial grouping of DHF cases in metropolitan areas and Southern Taiwan which is a green space for landscaping [9]. In Queensland, Australia, the incidence of dengue fever also clustered around Cairns and occurred in autumn [10]. The spatial and temporal results of the fever in Guangdong China showed the incidence of centralized outbreaks in the Yuexiu District and spread to several surrounding districts in Guangzhou and Guangdong Province [11]. Provinces with a large number of case counts, urban population, urban land cover and incoming flight passengers are associated to the epidemic prone cluster of dengue in Thailand [12]. From several spatial studies, it is important to pinpoint the area of distribution and timing in controlling DHF.

GIS and spatial statistics were frequently used to characterize spatiotemporal patterns of dengue and other infectious diseases. Acharya et al. in Nepal assessed spatiotemporal patterns of dengue in Nepal combining the address and district levels [13]. SaTScan software provides a powerful tool to detect, delineate, and validate disease clusters, risk population, and factors associated with them over space and time. Further SaTScan adjusts for confounding variables, and reduces preselection bias regarding the size and location of cluster [13]. This study uses analysis spasiotemporal at the subdistrict level. Spatiotemporal analysis indices correlated with the highest DHF density: high transmission intensity only, long duration, and high transmission intensity plus long duration [14]. This analysis could provide useful information to identify areas at high risk of DHF and time. This information about analysis spasiotemporal DHF in subdistrict level may be helpful to the development of related epidemic prevention and control strategies in Banyumas district.

The results of the spatiotemporal information on DHF are used as a tool in formulating policies, making decisions, and implementing activities related to DHF. Also, spatiotemporal analysis in epidemiology is very useful, especially to evaluate the occurrence of differences in incidence by geographic area and identify disease clustering. The benefits of clustering analysis include showing the geographical surveillance of disease, identifying disease clusters spatially or space-time and, determining whether the clusters are statistically significant [15]. The results of this spatiotemporal analysis are used as control information, therefore the target and timing of its implementation are right. Therefore, this study aimed to determine the spatiotemporal distribution and grouping of DHF cases in sub district level in Banyumas 2018.

\section{RESEARCH METHOD}

The study design was observational with a cross-sectional spatial analysis. It was conducted in the Banyumas area with 57 DHF cases recorded at the Banyumas Health Office in 2018. The studied variables include the house of dengue fever patients, date of illness, location of health center services, population density in villages or sub-districts, land use, rain, rivers, and rock types. The data were collected from several sources, namely primary and secondary. The secondary data were obtained from the public health center (Puskesmas), Statistics Indonesia, National Meteorology Climatology Geophysics Agency, Civil Registry Service Office, and Regional Planning Organization. Furthermore, the primary data which include the coordinates of the patients' houses, the coordinates of Puskesmas, and height of the house were obtained using the geographical positioning system (GPS) tool. The geographic coordinates of the case are the coordinates of the house, which was done outside and in front of the house. The analysis includes overlay analysis, buffering, and clustering. Overlay analysis was used to determine the spread of DHF cases based on several variables such as land use, population density, rainfall, and rock types. Meanwhile, population density in this study is the number of people in each village. This variable was obtained by dividing the total population by the area of each village $\left(\mathrm{km}^{2}\right)$. Furthermore, buffering analysis was used to determine the 
spread of the disease, and the spatial elements used in this analysis are the existence of health services or centers and rivers. Clustering analysis was conducted with SaTScan software to determine the cluster or grouping of dengue events in space and time (space-time permutation model). Analysis of the space-time permutation model was visualized using the Arcmap 10.1 program. In addition, SaTScan analysis used the Space-Time Permutation Model (Likelihood Ratio Test) by analyzing significant clusters, namely the most likely and secondary cluster.

\section{RESULTS}

Banyumas Regency is a lowland with an average height of +108 meters above sea level, and located between 7015 '05 "- 70 37' 10" south latitude and 108039 '17 "-1090 27" 15 " north latitude. This regency has a land area of $1,327.59 \mathrm{~km}^{2}$ consisting of 27 sub-districts, with Cilongok as the largest $\left(105.34 \mathrm{~km}^{2}\right)$ and West Purwokerto as the smallest sub-district $\left(7.40 \mathrm{~km}^{2}\right)$. Based on the elevation (height above sea level), the plains in Banyumas Regency consist of: $0 \mathrm{~m}-100 \mathrm{~m}=54.86 \%, 101 \mathrm{~m}-500 \mathrm{~m}=45.14 \%$. This regency has a tropical climate with two seasons, namely dry and rainy. Throughout 2017, there was rainfall which fluctuated for 153 days and varied by month. The highest rainfall was recorded in October at $648.73 \mathrm{~mm}$, while the lowest was in August at $12.45 \mathrm{~mm}$. Furthermore, Banyumas Regency has a wet tropical climate with an average temperature of $26.5^{\circ} \mathrm{C}$. The minimum temperature is around $24.4^{\circ} \mathrm{C}$ and the maximum is around $30.9^{\circ} \mathrm{C}[16]$

Banyumas has 27 sub-districts with 331 villages or wards and is led by a Regent and Deputy Regent. Based on population projections in 2017, the number of people in this regency is $1,665,025$, consisting of 831,816 men and 833,209 women. Cilongok is the sub-district with the largest population with 118,366 people and Purwojati is the smallest with 32,025 people. The population density in Banyumas Regency in 2017 was 1,254 people $/ \mathrm{km}^{2}$ with an average of 3.6 people per household. The population density in 27 sub-districts is quite diverse, with the highest in North Purwokerto of 7,326 people/ $\mathrm{km}^{2}$ and the lowest in Lumbir of 433 people $/ \mathrm{km}^{2}$. Also, the health facilities owned by Banyumas Regency are two hospitals and 39 health centers, a Community Health Laboratory, Community Eye Health Center, Community Lung Health Center, as well as Kartini Mother and Child Public Health Center [16]. The data showed that the DHF cases in Banyumas from 2009-2018 were 3,610. The highest occurred in 2016 with 990 cases and the lowest occurred in 2018 with 57 cases. The highest incidence rate was in 2016 at 55/1000 population and the lowest was in 2009 at 2/1000. In 2018, 57 dengue cases were reported in Banyumas, and have spread throughout the area. The following is a description of the 57 cases DHF in 2018. The gender characteristics of the patients are almost the same between men and women, with a slight difference. Most of patients were women $(54 \%)$ as shown in Table 1.

Table 1. Characteristics of DHF patients

\begin{tabular}{ccc}
\hline Characteristics & & Statistics \\
\hline Age & Average & 25 years old \\
& Youngest & 3 month \\
& The oldest & 81 years old \\
Characteristics & Total & Percentage $(\%)$ \\
Male & 26 & 46 \\
Female & 31 & 54 \\
Total & 57 & 100 \\
\hline
\end{tabular}

DHF cases in Banyumas have an upward trend from September to December. The peak occurred in December with 17 cases $(29.8 \%)$. The two week graph showed that there are always DHF cases reported, which showed that the fever occur for two weeks as shown in Figure 1.

The following is the DHF cases distribution at Banyumas Regency in 2018. There are 57 cases dominated by the areas that are close to the central government in Purwokerto. Below is a map of the cases distribution. Figure 2 showed that the distribution of dengue cases was mostly in three sub-districts, namely East and West Purwokerto, as well as Somogede. This distribution area was obtained by calculating the area based on the outermost points of the DHF case. 


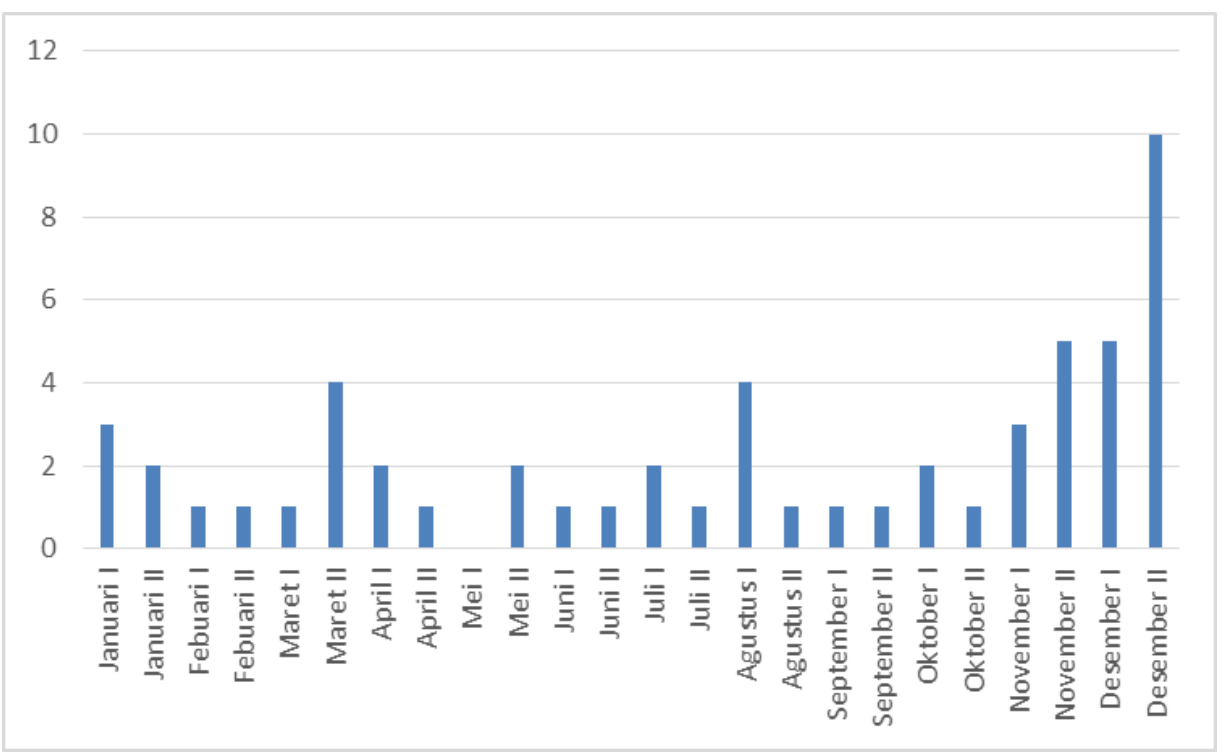

Figure 1. 2-Weekly graph of DHF

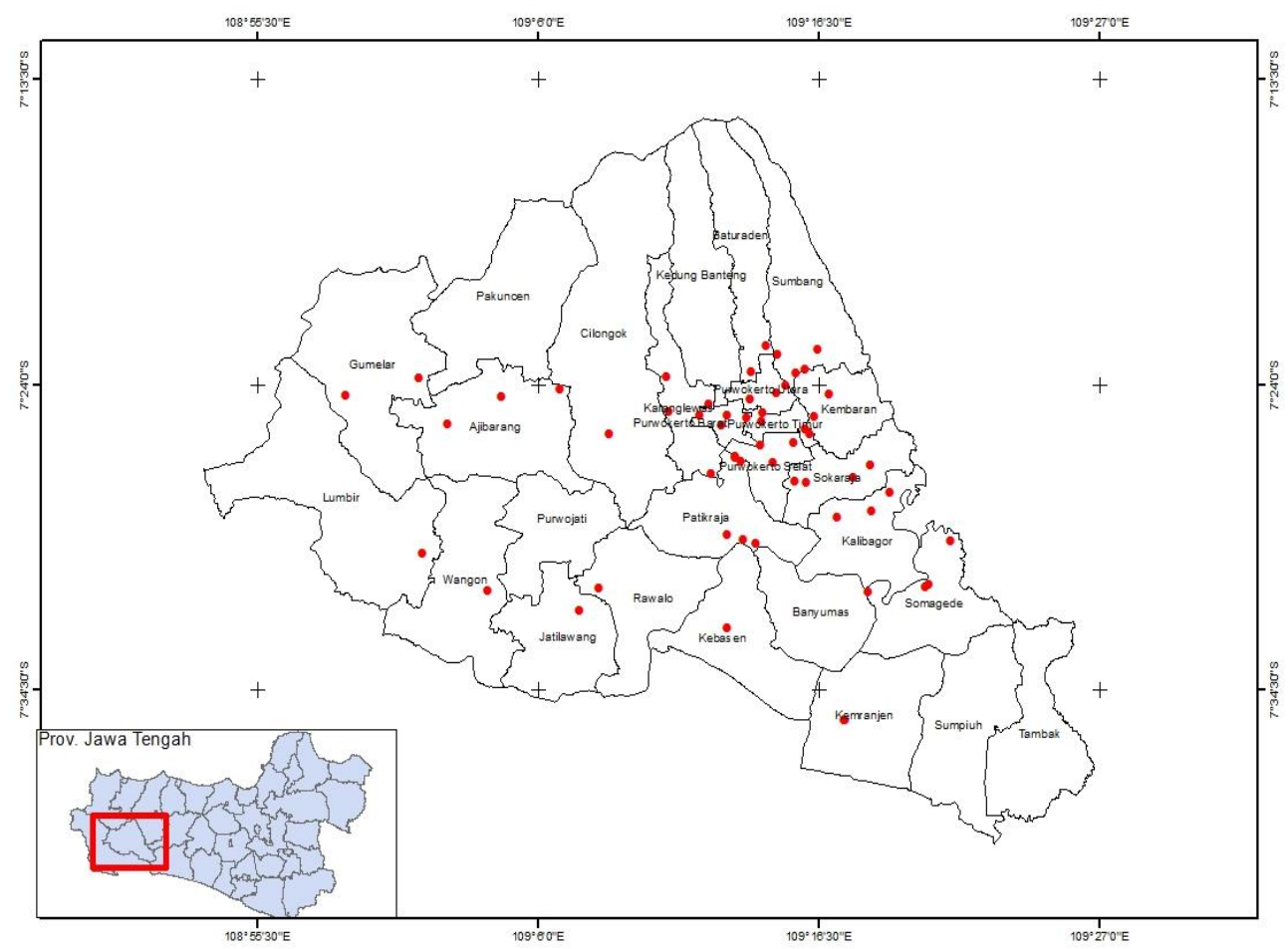

Figure 2. Distribution of DHF cases

Figure 3 shows that DHF cases were mostly found in areas with moderate rainfall. In areas with fewer rainfalls, the incidence tends to be less. The areas with light or fewer rainfalls include Kebasen, Banyumas, Somagede, Kemranjen, Rawalo, Jatilawang, Wangon, Ajibarang, Gumelar and Lumbir Subdistricts. In addition, the urban area in Banyumas, around Purwokerto has moderate rainfall. Buffering on this map is the location of health facilities, which include hospitals, health centers, and polyclinics. 


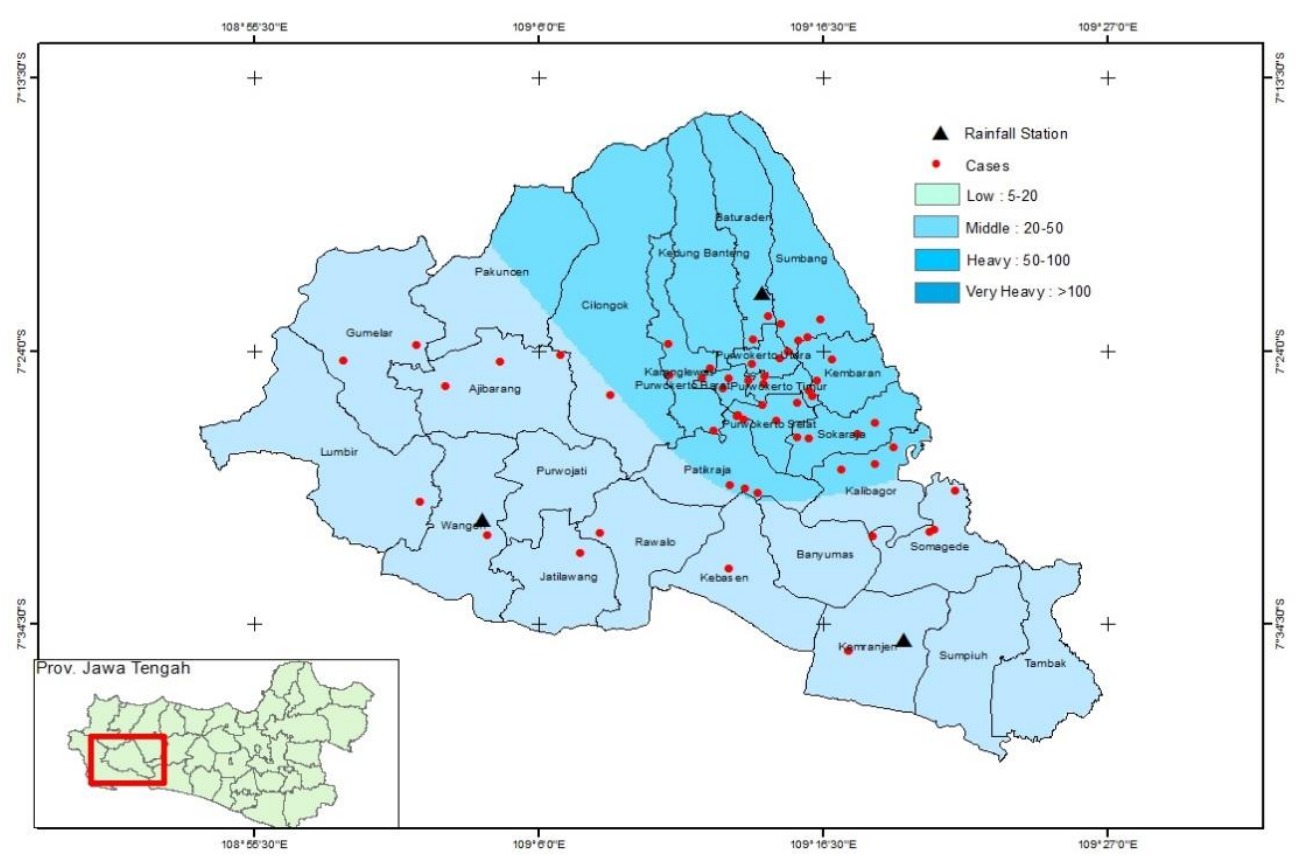

Figure 3. Rainfall overlay with DHF cases

The results of the analysis showed that most of the DHF cases are located close to health facilities, which is within a radius of less than $1 \mathrm{~km}$ as shown in Figure 4. The Figure 5 shows that the distribution of DHF cases did not approach the river flow. There are many rivers in Banyumas, and the cases do not occur in river basins. Population density was obtained by finding the sub-district area divided by the total population. The darker blue color indicates a higher density. The following is a buffering map for dengue cases with rivers at Banyumas.

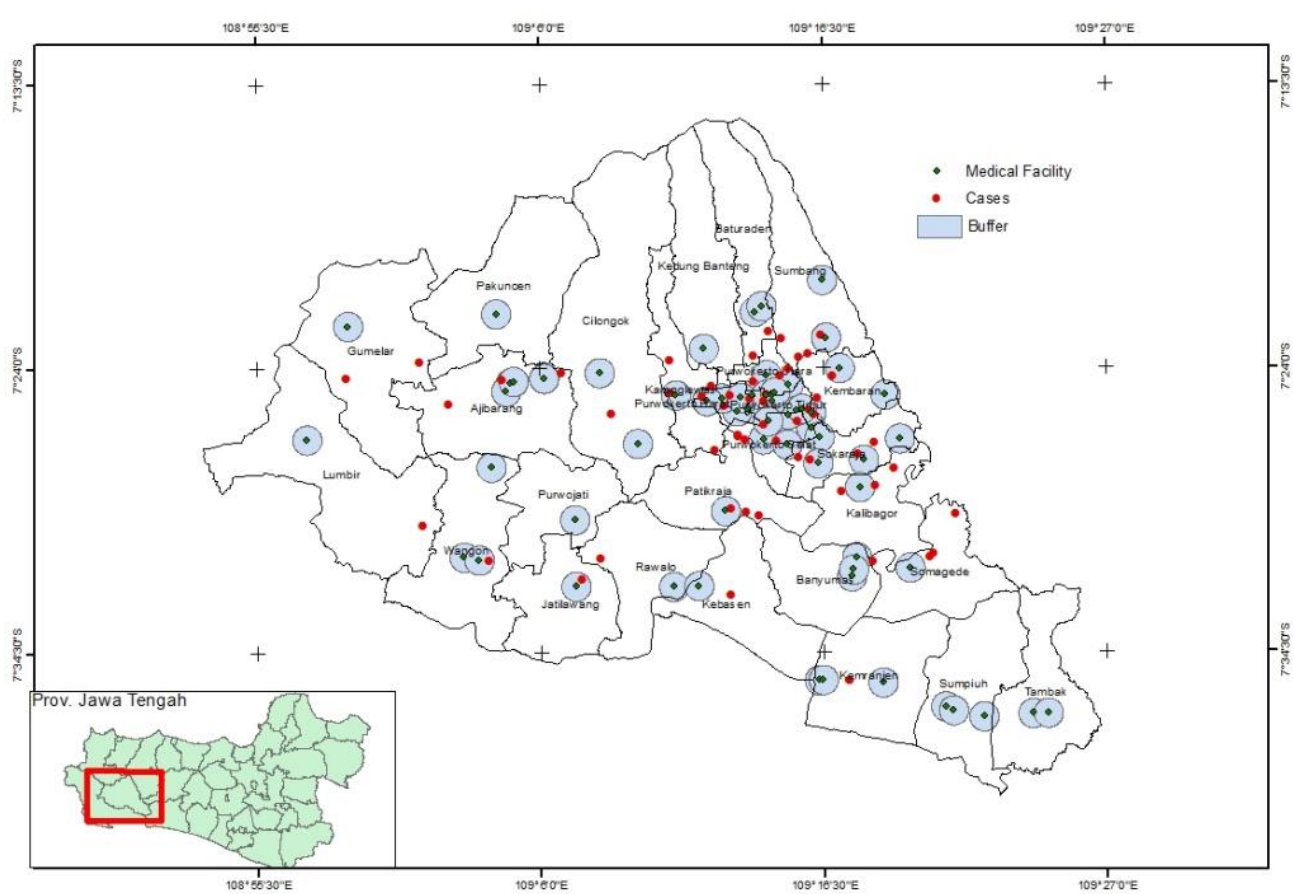

Figure 4. Buffering map of DHF cases with health facilities in Banyumas Regency 


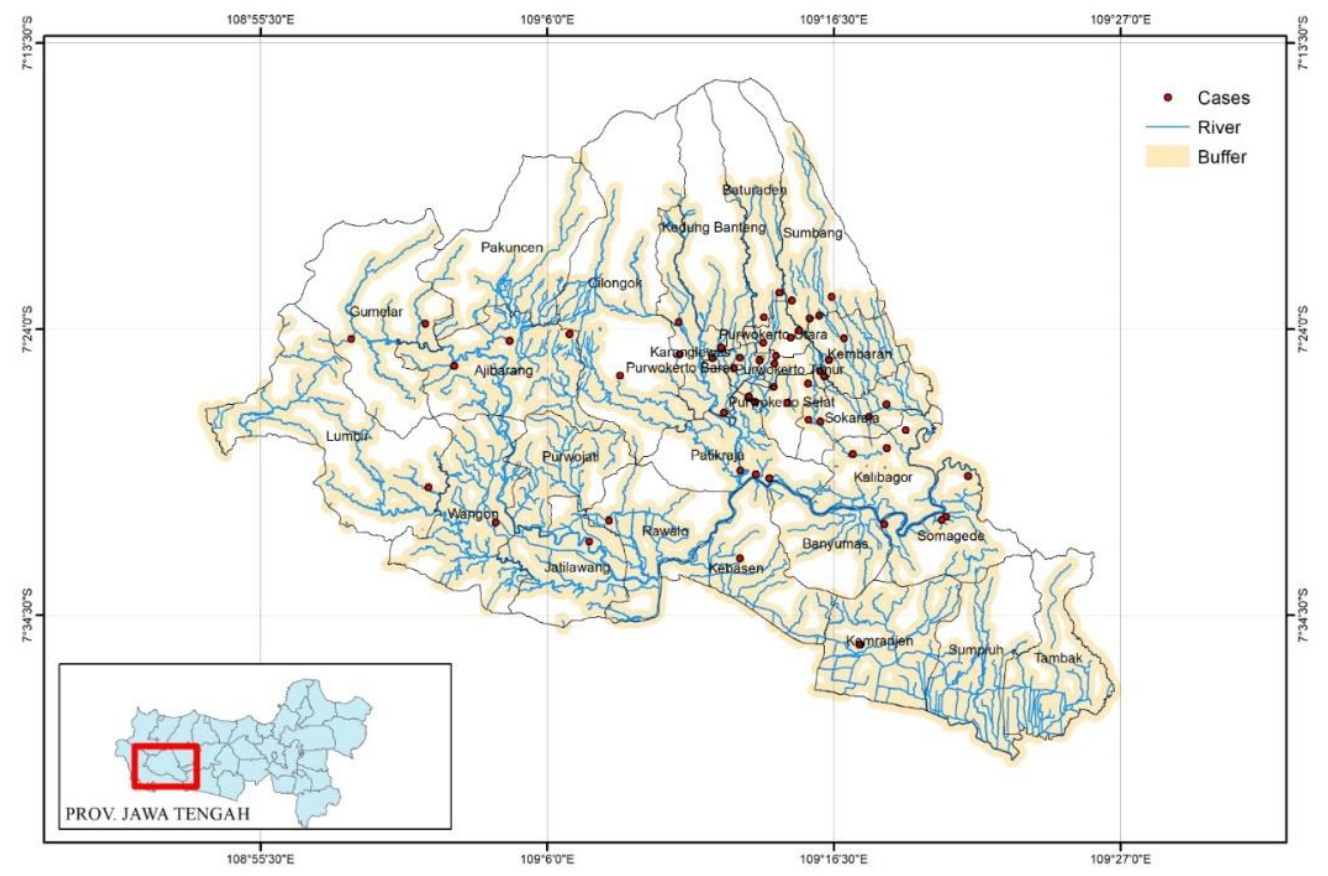

Figure 5. Buffering Map of DHF Cases with rivers in Banyumas Regency

Figure 6 reveals that the DHF cases occurred in the more densely populated sub-district. In sparsely populated areas, there are fewer cases. Meanwhile, Purwokerto urban area which includes North, South, East, and West has a higher population density and also more dengue cases. Areas with the highest population density (>1250 people/ $\mathrm{km}^{2}$ ) are in North, South, West, and East Purwokerto, Kembaran, Sokaraja, Wangon, Ajibarang, Sumbang as well as Karanglewas Subdistrict. Meanwhile, the areas with the lowest population density $\left(<500\right.$ people $\left./ \mathrm{km}^{2}\right)$ are Lumbir and Gumelar Subdistrict. Spatially, it showed that the highest cases occurred in urban areas, namely North, South, West, and East Purwokerto Subdistrict with high population density rates. In addition, the areas with the lowest cases, namely Lumbir, have low population density.

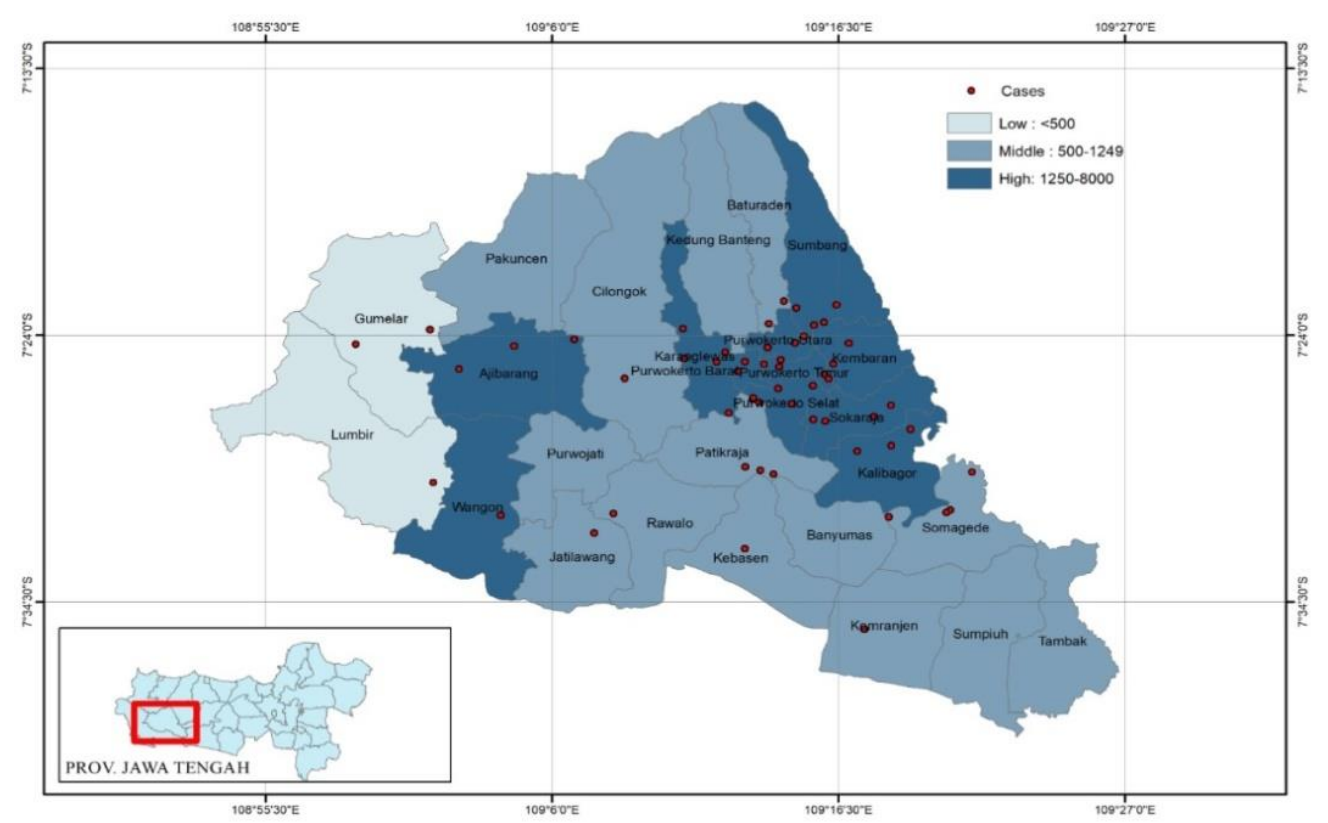

Figure 6. Overlay map of DHF cases with population density in Banyumas Regency in 2018 
The following are the color symbols in the land use map in Banyumas. The colors are gray (buildings), green (forests or hills), brown (field land), pink (settlements), blue (swamps) and orange (rice fields). The map showed that the cases were mostly in residential areas. In green areas, such as hills and forests, it was reported that the cases are rarely found as shown in Figure 7. The clustering analysis results of DHF cases at Banyumas Regency in 2018 as shown in Figure 8.

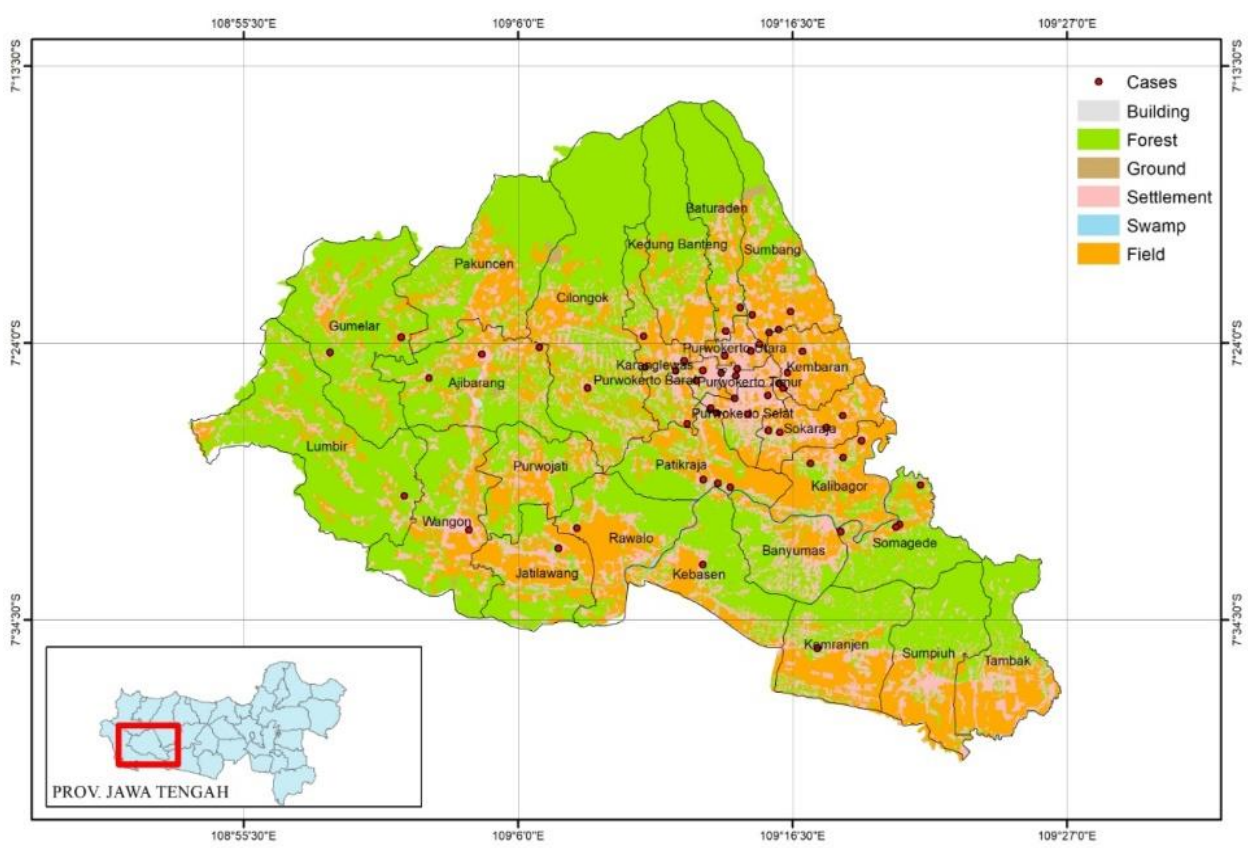

Figure 7. Overlay map of DHF cases with land use at Banyumas Regency in 2018

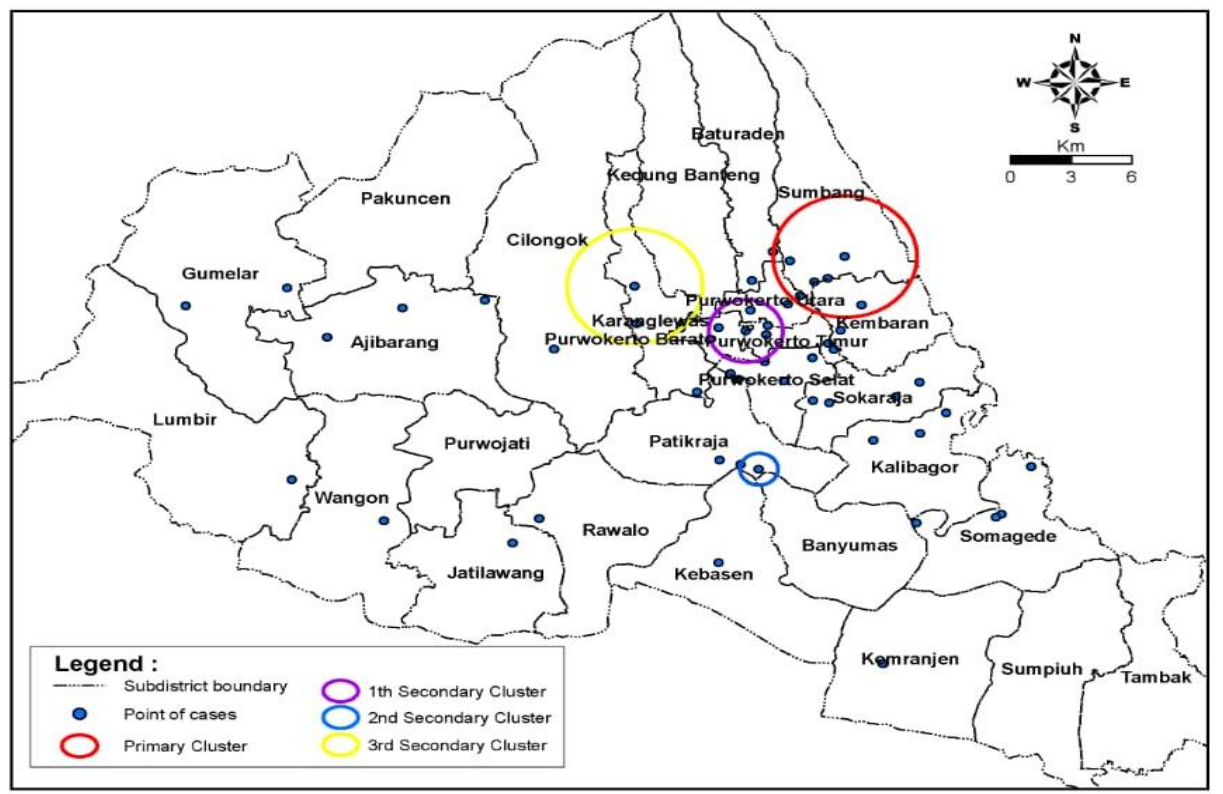

Figure 8. The clustering analysis results of DHF cases at Banyumas Regency in 2018

The analysis results with Satscan showed that the clustering of dengue cases resulted in the most likely cluster (primary cluster) and three secondary clusters. Most likely clusters (primary clusters) occur on March 13 to April 23, 2018 with six cases and centered on the coordinate point (-7.380000 S, 109.273611 E) 
with a grouping radius of $3.53 \mathrm{~km}$ and statistically significant $(\mathrm{p}=0.001)$. This primary cluster area is a combination of four administrative regions, which are Kembaran, Sumbang, Baturaden and North Purwokerto Sub-districts. Based on the Satscan results, it can be concluded that the distribution of DHF cases in Banyumas Regency is not random. This explains that as long as there is one dengue patient in one area, residents who lives within a radius of $3.53 \mathrm{~km}$ have a very high chance (high risk) of being infected.

The first secondary case grouping in East and North Purwokerto Sub-districts was centered on the coordinate point $(-7.418889 \mathrm{~S}, 109.22944 \mathrm{E})$ with a grouping radius of $1.82 \mathrm{~km}$. As many as five cases occurred on June 19, to August 13, 2018 and were not statistically significant $\mathrm{p}=0.200$.

The second secondary case grouping in Patikraja Subdistrict was centered on the coordinate point $(-7.491111 \mathrm{~S}, 109.23527 \mathrm{E})$ with a grouping radius of $0.93 \mathrm{~km}$. As many as two cases occurred on August 14 to September 10, 2018 and were not statistically significant $\mathrm{p}=0.375$.

The third secondary case grouping in Karanglewas Subdistrict was centered on the coordinate point (-7.395556 S, 109.180000 E) with a grouping radius of $3.33 \mathrm{~km}$. As many as three cases occurred on September 25 to November 5, 2018 and were not statistically significant $\mathrm{p}=0.540$.

\section{DISCUSSION}

There was a clustering of dengue cases, which consisted of one primary and three secondary clusters. The primary cluster location covers 4 sub-districts, namely Kembaran, Sumbang, Baturaden, and North Purwokerto. This showed that there is dengue transmission in the area. Also, as long as there is one patient in an area, people who live within a radius of three kilometres have a risk of contracting the disease. The areas identified as primary clusters are a combination of urban and suburban areas. The urban areas are synonymous with densely populated areas; therefore when there are people with infectious diseases, the possibility of spreading it will increase. Furthermore, the mobility of population from one area to another has further increased the spread of infectious diseases. The results of research in Rembang, Indonesia showed that the mobility of population in sub-district or regency is a potential for dengue transmission [17]. Research in Italy showed that foreign tourists traveling for a relatively long time need to carry out serological surveillance related to the spread of dengue. This is because there is no licensed vaccine used to prevent the disease [18]. One of the risk factors for secondary infection that causes DHF is a history of having been previously exposed and migration to urban areas [19]. Similar results in Amazonia showed that villagers visiting urban areas are at risk for contracting dengue [20]. Meanwhile, primary clusters in Banyumas were detected from March to April. In Bali, strong seasonality of dengue incidence was observed during January to May [21] and Southeast Sulawesi Indonesia, the highest rate of dengue cases was found in January- March [22]. This result is different from the study in Pakistan which showed that the primary cluster was detected from August to October and the secondary was detected in September [23].

In 2018, DHF cases spread in almost all areas of Banyumas Regency, and the cases tended to increase compared to 2016-2017. This Regency is one of the areas in Central Java Province which is generally considered a rural area. Furthermore, this region is still dominated by active agricultural areas and part of the community depends on agricultural sector for their livelihoods. However, there are several subdistricts which are urban areas, especially in Purwokerto city and its surroundings. Purwokerto is the place for regional government offices; therefore this area is dominated by fairly complete offices and infrastructure. Recent studies showed that the incidence of DHF occurred in densely populated urban and in rural areas.

Overlay of DHF cases in Banyumas Regency uses land use variables, population density, and rainfall. The analysis results showed that the cases were mostly in relatively dense residential areas. In urban areas, Aedes aegypti is more common, while in rural, Aedes albopictus is more common, this is related to land use. The distribution of Aedes aegypti and Aedes albopictus in urban areas is found in areas with residential land use. Meanwhile, the distribution of Aedes aegypti and Aedes albopictus in rural areas is found in areas with residential land use surrounded by gardens [24].

The spread of DHF is mostly found in densely populated areas. Meanwhile, density is not a major cause of the incidence, but it is an important risk factor in its development. The high population density and the close distance between houses causes the spread of DHF to be more intensive in urban areas. This is related to the flight distance of mosquitoes up to an average of 100 meters [25]. Furthermore, the denser population density in an area causes transmission to be easier and faster. In fact, the higher the population mobility, the more the transmission from one place to another. This is because dengue virus can be transmitted quickly as long as the place is an endemic area [26]. Statistical test results also showed that there is a relationship between population density and the incidence of DHF. Areas that are densely populated tend to have more cases than less dense areas [27]. 
DHF cases in Banyumas are more common in areas with moderate rainfall, while areas with little rainfall have few cases. This result is consistent with a study in Jakarta which showed a relationship between rainfall and the incidence of dengue fever. When the rainfall is high, the hourly perching rate of Aedes mosquitoes also increases. During the rainy season, water reservoirs increase and are used by Aedes $s p$. to lay eggs [28].

In Thailand, dengue outbreaks coincide with the rainy season, mean rainfall and maximum temperature were positively associated with dengue incidence [29]. Therefore, climate is very important in the transmission of vector-borne diseases such as dengue fever, especially in the highlands of tropics. Although rainfall has no direct effect, it plays a role in transmission. The presence of rain forms a collection of water which can serve as a breeding place for Aedes sp. Furthermore, high rainfall increases humidity and extend the life of adult mosquitoes. Rainfall can either increase or eliminate the number of breeding places, and also affects the temperature and relative humidity of the air. Therefore, rainfall is an important climate element in vector density because high levels can cause standing water which has the potential as a breeding site for Aedes Aegepty mosquitoes [25].

Buffering of DHF cases based on the existence of health services or public health centers showed that most cases are in areas close to health services in the form of hospitals (less than one kilometre). The average, minimum, and maximum distances of DHF cases from the health center are 1,613 meters, 263 meters, and 5,625 meters, respectively. The results of previous research showed that some of the cases were located within four kilometres radius of Margono Soekardjo Hospital [30]. The study in Semarang stated that there was a relationship between access to health services and the incidence of death due to dengue. Those that died likely have difficult access to health services, while those that are alive have easy access to health services [31]. The buffering results of the cases on rivers showed that the distribution does not approach the river flow. The study in Rembang, Indonesia stated that DHF cases located in zone buffer 0-100 $\mathrm{m}$ from puddle [17].

\section{CONCLUSION}

One primary and three secondary clusters of dengue were detected in Banyumas Regency in 2018. The primary cluster occurred in March-April, involving four sub-districts in urban areas, namely Kembaran, Sumbang, Baturaden, and North Purwokerto. Therefore, the significantly identified clusters indicate dengue transmission in Banyumas Regency with a radius of three kilometres.

\section{ACKNOWLEDGEMENTS}

Authors are grateful to Research Institution and Community Service (LPPM), Universitas Jenderal Soedirman, Indonesia for providing funding to conduct this study.

\section{REFERENCES}

[1] Indonesia Health Ministry, "Indonesia health profile 2017/profil kesehatan Indonesia tahun 2017," 2018.

[2] Indonesia Health Ministry, "Profil kesehatan Indonesia tahun 2016/Indonesia health profile 2016," 2017.

[3] Banyumas Health Office, "Health profile of Banyumas Regency in 2017/Profil kesehatan Kabupaten Banyumas tahun 2017," 2018.

[4] D. Oktaviana, S. P. M. Wijayanti, S. Nurlaela, Kuswanto, "Evaluation of Dengue prevention and control programs in Banyumas Health office, Central Java, Indonesia," International Journal Public Health Clinical Sciences, vol. 6, no. 1, pp. 199-208, 2019, doi: 10.32827/ijphcs.6.1.199.

[5] Indonesia Law, "Undang-Undang Republik Indonesia Nomor 4 Tahun 2011 tentang informasi geospasial/ Law of the Republic of Indonesia Number 4 of 2011 concerning Geospatial Information,” 2011.

[6] A. C. Clements, H. L. Reid, G. C. Kelly, and S. I. Hay, "Further shrinking the malaria map: how can geospatial science help to achieve malaria elimination?," Lancet Infectious Diseases, vol. 13, no. 8, pp. 709-718, 2013, doi: 10.1016/S1473-3099(13)70140-3.

[7] M. A. de Oliveira, H. Ribeiro, and C. Castillo-Salgado, "Geospatial analysis applied to epidemiological studies of dengue : a systematic review Análise geoespacial aplicada em," Revista Brasileira de Epidemiologia, vol. 16, no. 4, pp. 907-917, 2013, doi: https://doi.org/10.1590/S1415-790X2013000400011.

[8] M. Hazrin et al., "Spatial Distribution of Dengue Incidence: A Case Study in Putrajaya," Journal of Geographic Information System, vol. 8, no. 1, pp. 89-97, 2016, doi: 10.4236/jgis.2016.81009.

[9] C. C. Huang, T. Y. T. Tam, Y. R. Chern, S. C. C. Lung, N. T. Chen, and C. Da Wu, "Spatial clustering of dengue fever incidence and its association with surrounding greenness," International Journal Environmental Research Public Health, vol. 15, no. 9, pp. 1-12, 2018, doi: 10.3390/ijerph15091869.

[10] R. Akter, S. Naish, M. Gatton, H. Bambrick, W. Hu, and S. Tong, "Spatial and temporal analysis of dengue infections in Queensland, Australia: Recent trend and perspectives," PLoS One, vol. 14, no. 7, pp. 1-13, 2019, doi: 10.1371/journal.pone.0220134. 
[11] M. Sanna, J. Wu, Y. Zhu, Z. Yang, J. Lu, and Y. H. Hsieh, "Spatial and temporal characteristics of 2014 dengue outbreak in Guangdong, China," Scientific Reports, vol. 8, no. 1, pp. 1-10, 2018, doi: 10.1038/s41598-018-19168-6.

[12] J. T. Lim, Y. Han, B. S. L. Dickens, E. L. W. Choo, L. Z. X. Chew, and A. R. Cook, "Revealing two dynamic dengue epidemic clusters in Thailand," BMC Infectious Diseases, vol. 20, no. 1, pp. 1-11, 2020, doi: 10.1186/s12879-020-05666-4.

[13] B. K. Acharya, C. Cao, T. Lakes, W. Chen, and S. Naeem, "Spatiotemporal analysis of dengue fever in Nepal from 2010 to 2014," BMC Public Health, vol. 16, no. 1, pp. 1-10, 2016, doi: 10.1186/s12889-016-3432-z.

[14] T.-H. Wen, C.-C. K. Neal H Lin, Day-Yu Chao, et al., "Spatial-temporal patterns of dengue in areas at risk of dengue hemorrhagic fever in Kaohsiung, Taiwan, 2002," International Journal Infectious Disease, vol. 14, no. 4, pp. 334-343, 2010.

[15] D. Wulan, S. Rengganis, W. Lutfan, L. Yodi, and M. Hari, "The Importance of spatial-based cluster analysis in tuberculosis control in Indonesia/Pentingnya Analisis Cluster Berbasis Spasial dalam Penanggulangan Tuberkulosis di Indonesia," Kesmas (Jurnal Kesehat. Masy. Nasional), vol. 8, no. 4, pp. 147-151, 2013.

[16] Badan Pusat Statistik Banyumas, "Banyumas in Figures 2018/Banyumas dalam Angka tahun 2018," 2019.

[17] Nyarmiati, "Spatial analysis of environmental risk factors for dengue hemorrhagic fever/Analisis spasial faktor risiko lingkungan pada kejadian demam berdarah dengue," HIGEIA Journal Public Health Research Devolepment., vol. 2, no. Oktober 2017, pp1-11, 2017.

[18] D. Loconsole, A. Metallo, A. L. De Robertis, et al., "Seroprevalence of Dengue virus, west nile virus, chikungunya virus, and zika virus in international travelers attending a travel and migration center in 2015-2017, Southern Italy," Vector-Borne Zoonotic Diseases., vol. 18, no. 6, pp. 331-334, 2018, doi: 10.1089/vbz.2017.2260.

[19] A. Candra, "Dengue hemorrhagic fever epidemiology, pathogenesis, and its transmission risk factors," Aspirator Journal Vector Borne Diseases Studies., vol. 2, no. 2, pp. 110-119, 2010, doi: 10.22435/aspirator.v2i2.2951.

[20] M. U. F. Mônica da Silva-Nunes, Vanda AF de Souza, et al., "Risk factors for dengue virus infection in rural Amazonia: population-based cross-sectional survey," American Tropical Medicine Hygine., vol. 79, no. 4, pp. 485494, 2008.

[21] P. W. Dhewantara et al., "Spatial and temporal variation of dengue incidence in the island of Bali, Indonesia: An ecological study," Travel Medicine and Infectious Disease., vol. 32, no. May, p. 101437, 2019, doi: 10.1016/j.tmaid.2019.06.008.

[22] R. Tosepu, K. Tantrakarnapa, K. Nakhapakorn, and S. Worakhunpiset, "Climate variability and dengue hemorrhagic fever in Southeast Sulawesi Province, Indonesia," Environmental Science Pollution Research International, vol. 25, no. 15, pp. 14944-14952, 2018, doi: 10.1007/s11356-018-1528-y.

[23] S. Atique et al., "Investigating spatio-temporal distribution and diffusion patterns of the dengue outbreak in Swat, Pakistan,” Journal Infection Public Health, vol. 11, no. 4, pp. 550-557, 2018, doi: 10.1016/j.jiph.2017.12.003.

[24] N. Pramestuti, D. Anggun, and P. Djati, "Distribution of dengue hemorrhagic fever (DHF) vector in urban and rural areas in Banjarnegara Regency/distribusi vektor demam berdarah dengue (DBD) daerah perkotaan dan perdesaan di Kabupaten Banjarnegara,” Buletin Penelitian Kesehatan, vol. 41, no. 3, pp. 163-170, 2013.

[25] Masrizal and N. P. Sari, "Analysis of DHF cases based on climatic elements and population density using a GIS approach on flat land/Analisis kasus DBD berdasarkan unsur iklim dan kepadatan penduduk melalui pendekatan GIS di tanah datar," Journal Kesehatan Masyarakat Andalas, vol. 10, no. 2, pp. 166-171, 2016.

[26] B. R. Fitriana and R. Yudhastuti, "Relationship between temperature factors and cases of dengue hemorrhagic fever (DHF) in Sawahan District, Surabaya/Hubungan faktor suhu dengan kasus demam berdarah dengue (DBD) Di Kecamatan Sawahan Surabaya," Indonesian Journal Public Health, vol. 13, no. 1, p. 85, 2019, doi: 10.20473/ijph.v13i1.2018.85-97.

[27] W. Setyaningsih and D. A. Setyawan, "Geographical information system (GIS) modeling in the distribution of dengue hemorrhagic fever (DHF) in Karangmalang District, Sragen Regency/Pemodelan sistem informasi geografis (SIG) pada distribusi penyakit demam berdarah dengue (DBD) di Kecamatan Karangmalang Kabupaten Sragen," Journal Terpadu Ilmu Kesehatan, vol. 3, no. 2, pp. 209-214, 2014.

[28] M. M. Sintorini, "The influence of climate on cases of dengue hemorrhagic fever/Pengaruh iklim terhadap kasus demam berdarah dengue," Jurnal kesehata masyarakat nasional, vol. 2, no. 1, p. 11, 2007, doi: 10.21109/kesmas.v2i1.279.

[29] T. Phanitchat et al., "Spatial and temporal patterns of dengue incidence in northeastern Thailand 2006-2016," BMC Infectious Diseases, vol. 19, no. 1, pp. 1-12, 2019, doi: 10.1186/s12879-019-4379-3.

[30] Sunaryo, B. Ikawati, and D. Widyastuti, "Dengue hemorrhagic fever spatial distribution in Banyumas Regency, Central Java Province/Distribusi spasial demam berdarah dengue di Kabupaten Banyumas, Provinsi Jawa Tengah," Journal Ekologi Kesehatan, vol. 13, no. 4, pp. 289-297, 2014.

[31] M. Hikmah and O. W. Kasmini H, "Factors Associated with the Incidence of Dengue Hemorrhagic Fever Death/Faktor Yang Berhubungan Dengan Kejadian Kematian Akibat Demam Berdarah Dengue," Unnes Journal Public Health, vol. 4, no. 4, pp. 180-189, 2015, doi: 10.15294/ujph.v4i4.9693. 